\title{
Impact of Fiscal Decentralization on Local Autonomy in Sudan: Experience of Gadarif State
}

\author{
Sharif Ismail M. Bongo ${ }^{1}$
}

RESEARCH

ARTICLE

\section{ARTICLE INFO} \\ Submitted : 27.04.2019 \\ Revised : 01.07.2019 \\ Accepted : 18.07.2019 \\ Available : 30.07.2019 \\ iThenticate similarity \\ score: $6 \%$ \\ JEL classification: \\ $\mathrm{H} 50, \mathrm{H} 72, \mathrm{H} 77$

\section{Keywords:} \\ Fiscal Decentralization, \\ Expenditure And \\ Revenue Assignment, \\ Local Autonomy, \\ Federal Transfers
}

\begin{abstract}
A B S T R A C T
Based on state data of the periods (1997-2012), this study aimed at evaluating the fiscal decentralization experience of Gadarif state of eastern Sudan in the context of different aspects of fiscal decentralization, namely expenditure assignment, revenue assignment, and intergovernmental transfers. To accomplish these objectives, many local fiscal indicators have been calculated, and parameters of regressions of both revenues and expenditures have been estimated. The results reveal that the experience of fiscal decentralization of the state came out with poor fiscal situations indicated by higher dependence on the federal transfers and higher vertical imbalance and consequently the failure of the state government to perform its responsibilities of delivering the basic services to its constituents. Moreover, none of both local expenditure neither local revenues respond to federal transfers, indicating the failure of these transfers to realized their objectives.
\end{abstract}

\section{Introduction}

Fiscal decentralization - the devolution of taxing and spending powers to lower levels of government has become an important theme in governance in many countries

Cite this article as: Bongo, S. I. M. (2019). "Impact of Fiscal Decentralization on Local Autonomy in Sudan: Experience of Gadarif State", International Journal of Public Finance, 4(1), 99-126.

\footnotetext{
1 Department of Economics, ORCID: 0000-0002-7824-2753, University of Gadarif, Sudan, sharifbongo25@hotmail.com
} 
in recent years. Accordingly, restructuring of governmental functions and finances between the national and lower levels of government has entered the core of development debate. That is because "in most countries, the national government has failed to ensure regional equity, economic union, central bank independence, a stable macroeconomic environment, and local autonomy" (Shah, 2004).

Sudan was the largest country in Africa with a high level of diversification in ethnicity and resources. It ruled by central elites mostly in military fashion, controlling economic resources and political powers. These central minded elites consider the movement towards the decentralization as a threat to that legitimacy that may lead to fragmentation of political power and economic resources among different ethnic groups and regions. However, the move to the decentralization in Sudan is a result of the presser and resist to a dictatorship that causes conflicts and political instability.

The first step towards decentralization in Sudan was in 1948 when rural councils formed to hold the responsibility of delivering some services and collecting some revenues. The process of decentralization continues, and by the time, the sub-national governments have assigned more expenditures and revenues responsibilities.

The significant step for fiscal federalism in Sudan was after signing the Comprehensive Peace Agreement (CPA) between the government of Sudan and the Sudan People Liberation Movement (SPLM) in 2005. The agreement constitutes a set of institutional arrangements that should improve the federal system in Sudan. Thus, it is stated in the Wealth Sharing Protocol of the Agreement "decentralization and empowerment of all levels of government are cardinal principles of effective and fair administration of the country".

Nevertheless, the Sudanese experience of decentralization reveals the overwhelming existence of vertical and horizontal fiscal imbalance reflected in the failure of the lower levels of government to perform their assigned responsibilities in one hand and the existence of large fiscal disparities among different states of the country on the other hand.

Gadarif state is one of the 17 states of northern Sudan. It constitutes with Kassala and the Red Sea what was called the Eastern Region. The state experienced decentralization since 1995 when a republican decree issued increasing the number of states from 9 to 26 with the assignment of powers and revenues responsibilities. There are two levels of government, the state, and the local level. The number of localities reached 10 in 2008 and 12 in 2010.

In spite of that the constitution addresses the intergovernmental fiscal relations between the different levels of government, determining which taxes should be collected by which level of government and the expenditure to be carried out by different tiers of government, on one hand, the State government mandated to be responsible of much expenditure with narrow tax bases and fixed rates. On the other hand, buoyant taxes are assigned to the federal government and the state left with very low-income taxes. As a result, the vertical fiscal imbalance is expanded, reflecting the low performance of basic services delivery. 
Since the implementation of the federal system, the state faced many challenges in performing its responsibilities toward its constituents. Thus, the delivering of basic services of health, education, and water need to be financed by the state government under the federal system. The increasing of the dependence of the state government on the transfers of the central government put the state and local governments on the great challenge of performing its development projects in various localities. Thus, the actual assignment of responsibilities of health and education is not clear.

This study attempts to provide policy recommendations that would help to construct broad economic development strategies for the state with the aim of evaluating the process of fiscal decentralization comprehensively in Gadarif state during the period (1997-2012). To accomplish these goals the study addresses the following questions:

i. How fiscal decentralization experience of Sudan affects the financial situations in Gadarif state?

ii. What is the causes and size of fiscal imbalance in Gadarif state?

iii. Does the current system of fiscal transfers of the country acquire its objective of horizontal equity from the viewpoint of Gadarif state?

iv. At what extent the objective of local autonomy is realized in the state.

The study is organized as follows: section two reviews the theoretical and empirical literature. Section three outlines the historical background of fiscal decentralization experience of Sudan. Section four offers the summary of socioeconomic features of Gadarif state. Section five provides the empirical findings of the study. Section six concludes.

\section{Conceptual Framework}

Wallace Oates developed the basic work on fiscal decentralization in 1972. The major assumption underlying his theory is that a central government, due to imperfect information, will produce a uniform level of public goods across districts. While uniform provision is appropriate for goods with national benefits, such as national defense, it may be inappropriate for goods that are local in scopes, such as school funding and health clinic construction. Uniform funding for health clinic construction, for example, may be inefficient because it ignores heterogeneous tastes and preferences across districts. Perhaps one community wants more funding for health-related activities, while another prefers the money spent on local schools. Local governments can obtain better information about preferences, costs, and other idiosyncrasies unique to their constituency, at a lower cost (Oates, 1972).

From a public expenditure standpoint, Musgrave and Musgrave (1984) assert that public goods should be produced by the level of government whose constituents benefit from that provision. If the benefit is felt nationally, the public good should be produced by the central government. If the benefit accrues at the local level, local 
governments should provide the good. This is due not only to the informational advantage but also because local governments are closer to real resource costs.

In the event of a positive spillover-a situation in which one district benefits from the provision of the public goods of another district at no cost-the central government can internalize that spillover with the least amount of transaction costs (Smoke, 2001).

The substantial issue of fiscal decentralization is that of assigning responsibilities to the low levels of government. In this context, Oates (1999) argues that these responsibilities which range from the design to the implementation of various aspects of intergovernmental fiscal relations, raise several questions on the ground of which known in the literature of fiscal decentralization as the 'four basic building blocks or pillars' outlined as follows:

1. The assignment of expenditure responsibilities: what types of spending should be conducted by what levels of government?

2. The assignment of tax and revenue sources to different levels of government: what types of revenue should be raised and what tax rates should be set by what level of government? Also, which level is responsible for tax administration and the public expenditure management system?

3. Intergovernmental fiscal transfers: how should intergovernmental grants and revenue sharing be used to fill the gap between expenditures and revenues at subnational levels and provide the right incentives to sub-national governments? The fundamental question here is how the transfers are designed?

4. Sub-national borrowing: Which level should be able to finance its spending by borrowing from domestic or external sources, private or public?

The literature of fiscal decentralization focuses on studying the impact of fiscal decentralization on different aspects: economic efficiency, services delivery, poverty, economic growth, macroeconomic stability, and factors of governance etc. (Akai and Sakata, 2002). Regarding the issue of intergovernmental fiscal transfers, the emphasis is on in one hand, assessment of its impacts on sub-national governments' incentives and equalization. On the other hand, designing an appropriate system of transfers is the main issue perused by theoretical and empirical studies.

That said, evaluating the experience of fiscal decentralization of any country should come out through the above questions. However, the key issue in decentralization is "the coordination of intergovernmental fiscal relations, which has puzzled theoreticians and practitioners in recent years. Given increased complexity in coordinating government actions when lower levels of government enjoy greater autonomy of policymaking, the key policy challenge in decentralization programs is to design and develop an appropriate system of multilevel public finances in order to provide local public services effectively and efficiently while, at the same time maintaining macroeconomic stability" (de Mello, 2000). 


\subsection{Expenditure Assignment}

The expenditure responsibilities assignment defines who does what - which function is assigned to different government levels. There is no optimal assignment of expenditure responsibilities among different levels of government in the literature. However, the key principle in this context is what known in fiscal decentralization as the "subsidiarity principle". This principle suggests that government functions should be assigned to the level that is capable of efficiently undertaking this function. In general, this principle results in "a situation where, as far as possible, the area where a benefit of government service is felt coincides with the government boundaries at each level of government" (UNDP, 2005: 3).

The theoretical framework in this context generates several predictions. In particular: decentralization of expenditure responsibilities improves efficiency especially in countries with inter-regional heterogeneity of preference for public goods. Moreover, "the benefits of expenditures decentralization is higher the more local revenues are independents, and the better quality of governance at the local level is" (UNDP, 2005: 3). However, the subsidiarity principle suggests that three types of functions are the best performing by central government:

1- Provision of public goods and services that benefit the whole country (defense etc.);

2- Income redistribution or social policies (pensions, unemployment insurance)

3- Government activities that involve spill-overs or externalities between local governments

Regional or states governments are often assigned the provision of important public services, such as health, education, and police. Local governments (localities) provide local public services such as local roads, agriculture, water and sanitation, and recreation facilities.

This assignment of responsibilities is based on efficiency or equity reasons in the manner the particular expenditure program is designed and delivered. On efficiency ground, three sorts of arguments apply. First, program benefits may spill over to other communities; second, decentralized decision making can lead to inefficiencies because they distort cross-boundary transactions in product or factors. Third, fiscal competition among different sub-national governments may lead to the inefficient choice of expenditure programs. On the other hand, equity issues apply to state-level governments, which are responsible for providing public services such as health, education, and welfare, which can achieve redistributive goals that may be of national policy objective.

In general, the degree of discretion to lower levels of government differs from federation to another as does the manner at which that discretion constrained. 


\subsection{Revenues Assignment}

While the assignment of expenditure responsibilities among different tiers of government is mostly similar in different countries, the assignment of revenues sources varies widely among federations. In this context, the key question is what revenue sources assigned to sub-national governments? The answer to this question is related to the assignment of expenditure responsibilities: finance should follow function. In this regard, Shah (1991: 13) determined the consideration of revenue sources assignment as follows:

- Progressive redistributive taxes should be central.

- Taxes suitable for economic stabilization should be central.

- Lower level taxes should be cyclically stable.

- Tax bases distributed highly unequal between jurisdictions should be centralized.

- Taxes on mobile factors of production are best administered at the center residence.

- Based on taxes such as sales of consumption goods to consumers or excises are suited for states.

-Taxes on completely immobile factors are best suited for local levels;

- Benefit taxes and user charges might be appropriately used at all levels.

In general, tax assignment in various federations confirm to these guidelines, although there are individual cases of departure from these norms). Nevertheless, "one problem regarding the assignment of revenue sources in many countries is that while sub-national governments need to have at least some revenue discretion to fully benefit from fiscal decentralization reforms, central governments often seem unwilling to provide a significant degree of real revenue autonomy to sub-national governments" (UNDP, 2005: 4-5). In these cases, intergovernmental transfers become necessary to fill the revenue gap.

\subsection{Intergovernmental Transfers}

Intergovernmental fiscal transfers are a dominant feature of sub-national finance in most countries. They are used to ensure that revenues match the expenditure needs of various levels of sub-national governments. They are also used to advance national, regional and local objectives outlined in the literature as follows:

- Correcting or adjusting vertical imbalances: closing the fiscal gaps between expenditure assignments and revenue assignment.

- Compensating sub-national governments for complying with central government requirements of implementing delegated central government programs. 
- Correcting or adjusting horizontal imbalances: transfers can be used to "equalize" the level of service delivering among different sub-national governments.

- Correcting or adjusting externalities with public goods provision. Grants may be used to compensate local governments for services they deliver, which influence areas of near jurisdictions.

- Setting national minimum standards to preserve the internal common market and attain national equity objectives.

\subsection{Types of Intergovernmental Transfers}

There are two types of transfers to sub-national governments: conditional and unconditional. Conditional grants are also known as specific purpose grants, block, sectoral, categorical or earmarked grants. Unconditional grants, on the other hand, are also known as united or general- purpose grants.

When assessing a system of intergovernmental relations, there are two important policy questions to answer. First: is the system of intergovernmental fiscal relations fair to each level of government by providing sufficient resources to cover expenditure responsibilities? This question refers to vertical fiscal imbalances. Second: are there large fiscal disparities among different regions? This case refers to the horizontal fiscal imbalances (Vazquez, 2002).

This study seeks to evaluate the experience of fiscal decentralization of Gadarif state during the period (1997-2010) with special focus on expenditure assignment, revenue assignment and federal transfers to the state.

\section{Methodology}

According to the objectives of this study, different methods being utilized to attain these objectives. Thus, ratio analysis of some fiscal decentralization indicators will be carried out to evaluate the fiscal decentralization experience of Gadarif state in the context of the countries. Therefore, the following indicators are used:

Vertical Imbalance (VI), due to Hunter (1977):

$$
V I=1-\frac{\text { Own Revenue }}{\text { State Expenditure }}
$$

Revenue Effort (RE):

$$
R E=\frac{\text { Total Revenue }}{G D P}
$$

Concerning the objective of evaluation of the fiscal impact of the decentralization on the state, the study will use the following indicators: 
Bongo, S. I. M. (2019). "Impact of Fiscal Decentralization on Local Autonomy in Sudan:

Experience of Gadarif State", International Journal of Public Finance, 4(1), 99-126.

Tablo 1: Summary of Fiscal Decentralization Indicators

\begin{tabular}{|c|c|c|c|}
\hline Variables & Indicators & Description & $\begin{array}{c}\text { Level of } \\
\text { Measurement }\end{array}$ \\
\hline \multirow[t]{2}{*}{$\begin{array}{l}\text { Sub-national } \\
\text { government } \\
\text { expenditures }\end{array}$} & $\begin{array}{c}\text { Government expenditure } \\
\text { share }\end{array}$ & $\begin{array}{l}\text { The ratio of Sub-national } \\
\text { government spending to total } \\
\text { government spending }\end{array}$ & \multirow[t]{2}{*}{ Ratio Level } \\
\hline & Government Size & $\begin{array}{l}\text { The ratio of Sub-national } \\
\text { government spending to GDP per } \\
\text { government level }\end{array}$ & \\
\hline \multirow[t]{2}{*}{$\begin{array}{l}\text { Sub-national } \\
\text { government } \\
\text { revenues }\end{array}$} & $\begin{array}{l}\text { Sub-national Tax } \\
\text { autonomy }\end{array}$ & $\begin{array}{l}\text { The ratio of tax revenue to total } \\
\text { revenue of sub-national } \\
\text { government's }\end{array}$ & \multirow[t]{2}{*}{ Ratio Level } \\
\hline & $\begin{array}{l}\text { Sub-national non-tax } \\
\text { autonomy }\end{array}$ & $\begin{array}{l}\text { The ratio of non-tax revenues to } \\
\text { total revenues of sub-national } \\
\text { governments }\end{array}$ & \\
\hline $\begin{array}{l}\text { Intergovernmental } \\
\text { transfers }\end{array}$ & Vertical imbalance & $\begin{array}{l}\text { The ratio of intergovernmental } \\
\text { transfers to total sub-national } \\
\text { revenues }\end{array}$ & Ratio Level \\
\hline
\end{tabular}

Source: IMF, 2000.

In addition, regression analysis used to evaluate the experience of expenditure assignment, revenue assignment and intergovernmental transfers of the state. In this context, the following two simultaneous equations of total expenditure and own revenues are attempted:

$$
\begin{aligned}
& T E=\alpha_{0}+\alpha_{1} \text { Trans }+\alpha_{2} G D P+\mu_{t} \\
& \text { Strev }=\alpha_{0}+\alpha_{1} \text { Trans }+\alpha_{2} G D P+\mu_{t}
\end{aligned}
$$

Where

TE: the Total Expenditure

Trans: the Federal Transfers to the state

GDP: the GDP of the state

$\mu \mathrm{t}:$ The random variable; and

Strev: State own revenues.

Equations (1) and (2) explain at what extent the total state expenditure and own revenue respond to the variations in federal transfers and the GDP of the state.

\section{Fiscal Decentralization in Sudan: An Overview}

Sudan had experienced decentralization since 1948 when rural councils formed to hold the responsibility of delivering some services and collecting some revenues. A major decentralization policy change was initiated with the introduction of the 1951 Act. 
Under this Act, the government created councils with legal corporate status and clearly defined responsibilities (Elbattahani, 2008).

In 1972 the country witnessed another significant development in the government structure as a result of Addis Ababa peace agreement signing. Consequently, the Government of the Southern Region formed and granted a substantial degree of autonomy including tax levies. (Elshibly, 1990).

In 1974 the People` Local Government Act introduced important measure toward decentralizing the country. Accordingly, the country is divided into ten provinces and some functions like education, health and livestock shifted from the central government to the local councils with the same taxing powers.

The Regional Government Act of 1980 introduced further measures of decentralization. Hence, new regional governments created, given and granted a substantial degree of autonomy. No additional taxing powers are given to these regions other than previously performed by local councils and provinces (Elshibly, 1990).

The process of real fiscal decentralization in Sudan began in 1995 when a republican decree issued increasing the number of states from 9 to 26 with the assignment of powers and revenues responsibilities. The system proceeds with three tiers, federal, state and local. Accordingly, states governments have four sources of revenues as set in the constitution. These sources are:

Transfers from the federal budget through the Northern States Subsidy Fund (NSSF).

Off-budget transfers from the federal government of $43 \%$ percent of VAT collections and $10 \%$ of public enterprise profits.

(i) Revenues collected directly by the states through taxes, fees, and user charges; and

(ii) Loans and borrowing by the constitution.

On the other hand, local government revenues are a component of taxes on property, local transportation, local livestock production, and other local taxes or duties.

The significant step toward fiscal federalism in Sudan was after signing the Comprehensive Peace Agreement (CPA) between the government of Sudan and the Sudan People Liberation Movement (SPLM) in 2005. The agreement constitutes a set of institutional arrangements that should improve the federal system in Sudan. Thus, it is stated in the Wealth Sharing Protocol of the Agreement "decentralization and empowerment of all levels of government are cardinal principles of effective and fair administration of the country". That is of course in a decentralized system with significant devolution of power to the different levels of government, i.e., section (113) of the protocol states that "An expenditure function should be assigned to that level of 
government whose jurisdiction most closely reflects the geographical served by that function. The delivery of a particular service (expenditure assignment) may be carried out exclusively by a given level of government or by two or more".

On the revenues side, according to section (114) of the same protocol, "states levels of the government shall have the right to determine without national inference the structure of revenue base and the level of the charge or tax rate applied to that base". Moreover, the wealth-sharing protocol "provides a detailed breakdown of own source revenue for schedules all levels of government must radically reform their budgetary process"(Bell and Ahmed, 2005: 9).

To perform the task of implementing fiscal decentralization proceed as outlined above, many constitutional bodies and agencies established; i.e., Northern State Support Fund (NSSF) created to set criteria of distribution of the current and development transfers. The NSSF is based on nine criteria: financial performance, population density, natural resources, human resources, infrastructure condition, per capita income, education, and health and security situations. Each factor receives 10 percent weight except the financial performance, which receives 20 percent.

The Fiscal and Financial Allocation and Monitoring Commission (FFAMC) have been structured to ensure appropriate utilization and sharing of resources both vertically and horizontally, transparency and fairness in the allocation of funds among the states and to monitor and ensure that equalization grants from the national government are through a specific criterion based on the following:

1. Population size

2. Minimum expenditure responsibilities

3. Human Development Index - social indicators

4. Geographical areas

5. Fiscal efforts; and

6. The effect of the war factor.

The greater challenge in this context is how can the FFAMC perform, i.e., some questions may arise such as: how the allocation of such grants will be determined, how will be funded, by which level of government, etc. what sort of vertical and horizontal equalization is intended and how will be achieved? Bell and Ahmed (2005). However, political consideration still dominates the full implementation of the formula, which in turn jeopardizes the overall approach.

National Reconstruction and Development Fund (NRDF) is created to develop the war affected areas and the least developed areas taking the effect of war and level of development as the main criteria. 
Building on the Comprehensive Peace Agreement, the Joint Assessment Mission (JAM) formed in 2005 to develop a framework aiming at meeting the Millennium Development Goals (MDGs) for the people of Sudan, especially those in the south and other war-affected areas. The common themes of this framework include "the focus on broad-based and inclusive economic growth and empowerment of the people through a decentralized system of governance and services delivery" (JAM, 2005: 3).

According to the Interim National Constitute of (2005) the following table details the own revenue sources of the state level:

Tablo 2: Own Revenue Sources Assigned to States

\begin{tabular}{|c|c|c|}
\hline Revenue Type & Revenue Items & $\begin{array}{l}\text { Determination of } \\
\text { Collection/Allocation }\end{array}$ \\
\hline $\begin{array}{l}\text { Own Source } \\
\text { Revenue }\end{array}$ & $\begin{array}{l}\text { State land and property tax and royalties; service } \\
\text { charges for state services; state personal income tax; } \\
\text { levies on tourism; state government projects and } \\
\text { national parks; stamp duties; agricultural taxes; } \\
\text { grants-in-aid and foreign aid; excise duties; border } \\
\text { trade charges or levies in accordance with national } \\
\text { legislation; other state taxes, which do not encroach } \\
\text { on National or Southern Sudan Government taxes, } \\
\text { many other taxes, many other tax as may be } \\
\text { determined by } \\
\text { law. }\end{array}$ & $\begin{array}{l}\text { Combination of fiscal } \\
\text { base and effort and } \\
\text { effort by individual } \\
\text { states. } \\
\text { Potential bases provided } \\
\text { by Article } 193 \text { of the INC }\end{array}$ \\
\hline Shared Revenue & 2 percent of petroleum revenues by derivation & $\begin{array}{l}\text { The state share of } \\
\text { revenue based on } \\
\text { derivation Basis (and } \\
\text { other criteria), } \\
\text { established by CPA }\end{array}$ \\
\hline $\begin{array}{l}\text { Grands and } \\
\text { Transfers }\end{array}$ & $\begin{array}{l}\text { Current earmark transfers: } \\
\text { Wages (Judiciary, Police, High Education) } \\
\text { Social subsidies transfers } \\
\text { Current block transfers: agricultural taxes } \\
\text { compensation } \\
\text { Current transfers (largely for wages } \\
\text { Emergency and Ad hoc transfers } \\
\text { Development transfers: } \\
\text { State development projects (local component) } \\
\text { State development projects (foreign component) } \\
\text { Development and Reconstruction Funds for war- } \\
\text { affected areas. }\end{array}$ & $\begin{array}{l}\text { May be determined by } \\
\text { a formula, existing } \\
\text { establishment costs } \\
\text { (e.g., wages), or are in } \\
\text { a sense ad hoc and } \\
\text { discretionary. }\end{array}$ \\
\hline Borrowing & Loans/borrowing by the constitution & \\
\hline
\end{tabular}

Source: The Interim National Constitute of the Republic of the Sudan, 2005. 
Bongo, S. I. M. (2019). "Impact of Fiscal Decentralization on Local Autonomy in Sudan:

Experience of Gadarif State", International Journal of Public Finance, 4(1), 99-126.

\section{The Empirical Literature of Fiscal Decentralization in Sudan}

The fiscal trends of local governments in Sudan are characterized by many features. On the one hand, "the increase in demand on services coupled with the low share of development spending raises several questions regarding the states' commitment to long term development and macroeconomic stability. In addition to the administrative problems related to taxes, the local government may refrain from raising taxes too high due to political reason, adverse effects on both the people, especially the poor local economic development. The forms of taxation can be imposed on subsistence economies are very limited" (Gangi \& Ibrahim, 2008).

On the other hand, intergovernmental fiscal transfers in Sudan - with its six types (current transfer, development transfers, and additional support transfers, value-added taxes (VAT) and Benzene Transfers) increase as percentage of federal revenues from $2.7 \%$ in 1996 to $30 \%$ in 2005 suggesting that the ability of sub-national governments to finance their expenditure from their revenues declined from 92\% in 94/1995 to about $36 \%$ in 2005" (Elbaawi \& Suliman, 2007). Consequently, sub-national governments became increasingly dependent on central transfers, i.e., it reached $36 \%$ in 2006 and $38 \%$ of the federal government expenditure in 2007.

Furthermore, data on state level about the own source revenue collections which are available suggest that own source revenues shares in 2005 ranged from $66 \%$ in the Red Sea to $12 \%$ in North Darfur (World Bank, 2008). The level of reliance on transfers is greater, for the locality level in Gezira and North Kordofan states, over $80 \%$ of locality high share of the transfers that are earmarked.

Ali (2007) compared the current system of federal transfers of Sudan with that proposed by FFAMC according to its criteria; he concluded that under this assumption, all states, except the Nile state, would be receiving federal transfers, which are much higher than what the current system gives them.

On his analysis of fiscal decentralization in post-session Sudan, Mohamed (2017) argue that in the vertical aspect, the results have shown the overwhelming fiscal imbalance in the lower tiers of the government of Sudan. Moreover, the regression results revealed that none of the predictor variables, suggested by the FFAMC responds to the federal transfers indicating the failure of the transfers system of the country to reflect the need considerations.

However, most of the researches conducted in Sudan on the issue of fiscal decentralization ended with consistent results. Thus Elbattahani \& Gadkarim (2017) concluded that States and localities have only limited autonomy to make fiscal decisions, and accountability is missing. Local government officials are not accountable to local taxpayers. Recent government expenditures have been concentrated in the urban centers, which have been captured by politically connected elites. This continues the disenfranchisement, not only of the rural poor but also have large segments of the middle class in the peripheries. 
However, there is a large gap in the literature of fiscal decentralization in Sudan in the lower levels of governments, namely states and localities. This study attempts to take place in this gap.

\section{Gadarif State: A Socioeconomic Review}

Gadarif State, together with Kassala and Red Sea States, comprise the region of East Sudan as defined by the Eastern Sudanese Peace Agreement and consequent administrative arrangements. The state is located between longitudes 33ㅇ 30' and 36ㅇ $30^{\prime}$ to the East, and latitudes 12 $40^{\prime}$ and 15 $46^{\prime}$ to the North. Gadarif shares an international border with Ethiopia to its East. Nationally, Kassala and Khartoum State to the North, El Gezira State to the West and Sennar State to the Southern border the state.

The state's total population estimated to stand at some 1.35 million (Central Bureau of Statistics 2008) with an annual growth rate of 3.87\%. Over two-thirds of the populations live in rural areas and population density on a statewide basis stands at around 19 person perkm2. The total area of Gadarif state is calculated to be around $71,000 \mathrm{~km}^{2}$. The State is divided into twelve administrative localities.

\subsection{Population}

Table 3 below shows the statistics of the state populations and their growth according to different population censuses of the country.

Tablo 3: Population of the State According to the Different Censuses

\begin{tabular}{|c|c|c|}
\hline Year & Population & Growth rate \% \\
\hline 1973 & 580000 & - \\
\hline 1983 & 742000 & $28 \%$ \\
\hline 1993 & 1148262 & $55 \%$ \\
\hline 2008 & 1334947 & $16 \%$ \\
\hline
\end{tabular}

Source: CBS Office-Gadarif State, 2008.

Table 3 above shows the rapid increase of the populations of the state especially in the period (1983-1993) when the population increased by $55 \%$. This rapid increase is attributed to the great flow of immigrants from different parts of the country and the neighbor countries especially the African Horn countries for the reason of the great famine and drought destructed the region in this period. Tables 4 below shows the distribution of the populations of the state among different localities. 
Bongo, S. I. M. (2019). "Impact of Fiscal Decentralization on Local Autonomy in Sudan:

Experience of Gadarif State", International Journal of Public Finance, 4(1), 99-126.

Table 4: Distribution of population among different localities

\begin{tabular}{|c|l|c|c|}
\hline No. & Locality & Population & \% of Total \\
\hline 1 & Baladiyat El Gadarif & 269.395 & 20 \\
\hline 2 & Gadarif Center & 111.669 & 5.3 \\
\hline 3 & El Butana & 71.092 & 9 \\
\hline 4 & El Fashaga & 120.835 & 13 \\
\hline 5 & El Fao & 176.662 & 10 \\
\hline 6 & El Rahad & 135.682 & 4.5 \\
\hline 7 & El Mafaza & 60.756 & 8.4 \\
\hline 8 & East Gallabat & 113.334 & 7 \\
\hline 9 & West Gallabat & 91.875 & 3.5 \\
\hline 10 & Basonda & 47.562 & 6 \\
\hline 11 & El Gurreisha & 83.394 & 5 \\
\hline 12 & Gala El Nahal & 66.122 & 100 \\
\hline & Total & 1.348 .378 & \\
\hline
\end{tabular}

Source: Central Bureau of Statistics - Gadarif State.

\subsection{Selected Human Development Indicators}

Table 5 bellow exhibits some human development indicators for Gadarif state compared to that of the whole country.

Table 5: Selected Human Development Indicators for Gadarif State Compared to Sudan in 2012

\begin{tabular}{|l|c|c|}
\hline \multicolumn{1}{|c|}{ Indicator } & Gadarif & Sudan \\
\hline Mother Mortality Rate (each 100000) & 564 & 417 \\
\hline Child Mortality Rate <5 years (for each 1000) & 20.8 & 22.2 \\
\hline Total Fertility Rate & 4.8 & 3.9 \\
\hline Poverty Rate & 50.1 & 46.5 \\
\hline Unemployment Rate & 15 & 15.9 \\
\hline
\end{tabular}

Source: Central Bureau for Statistics - 2011.

\subsection{GDP}

Figure 1 below shows the GDP of the state during the period (2006-2012). The growth rate in this period is averaged 5.4\% (Ministry of Finance and Economy, Gadarif state 2014). 
Bongo, S. I. M. (2019). "Impact of Fiscal Decentralization on Local Autonomy in Sudan:

Experience of Gadarif State", International Journal of Public Finance, 4(1), 99-126.

Figure 1: GDP Of Gadarif State İn SDG Millions in the Period (2006-2012)

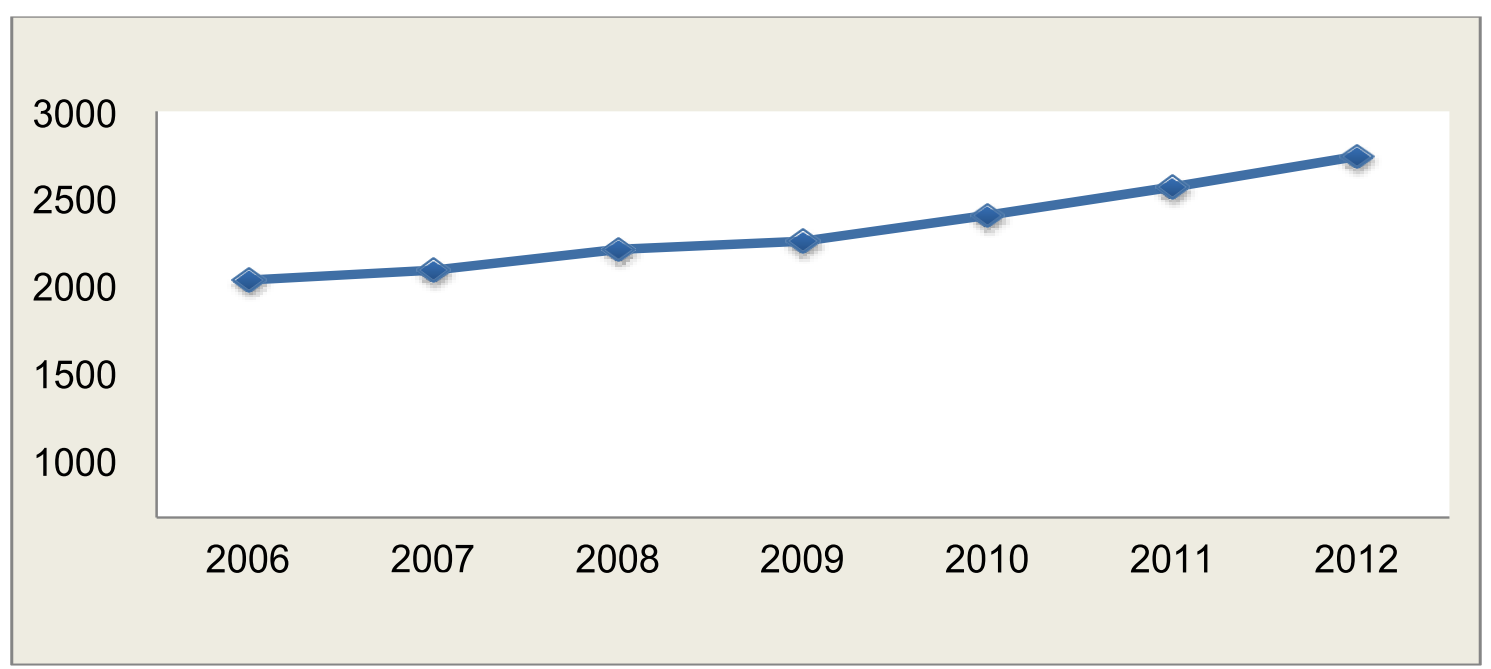

Source: Author' elaboration.

Agriculture is the main sector in the state economy; it contributes to about $79 \%$ in the GDP as shown below in Figure 2. Services sector constitutes $15 \%$ of the GDP of the state. The weakest sector in the state economy is the industrial sector, which contributes only $6 \%$ in the GDP during the period above in spite of the huge agricultural and livestock production of the state. This situation attributed to the weak infrastructures and absence of incentive policies and strategies encouraging the sector in the state.

Figure 2: Percentage Average Contribution of Different Sectors in GDP of Gadarif State During the Period (2006-2012)

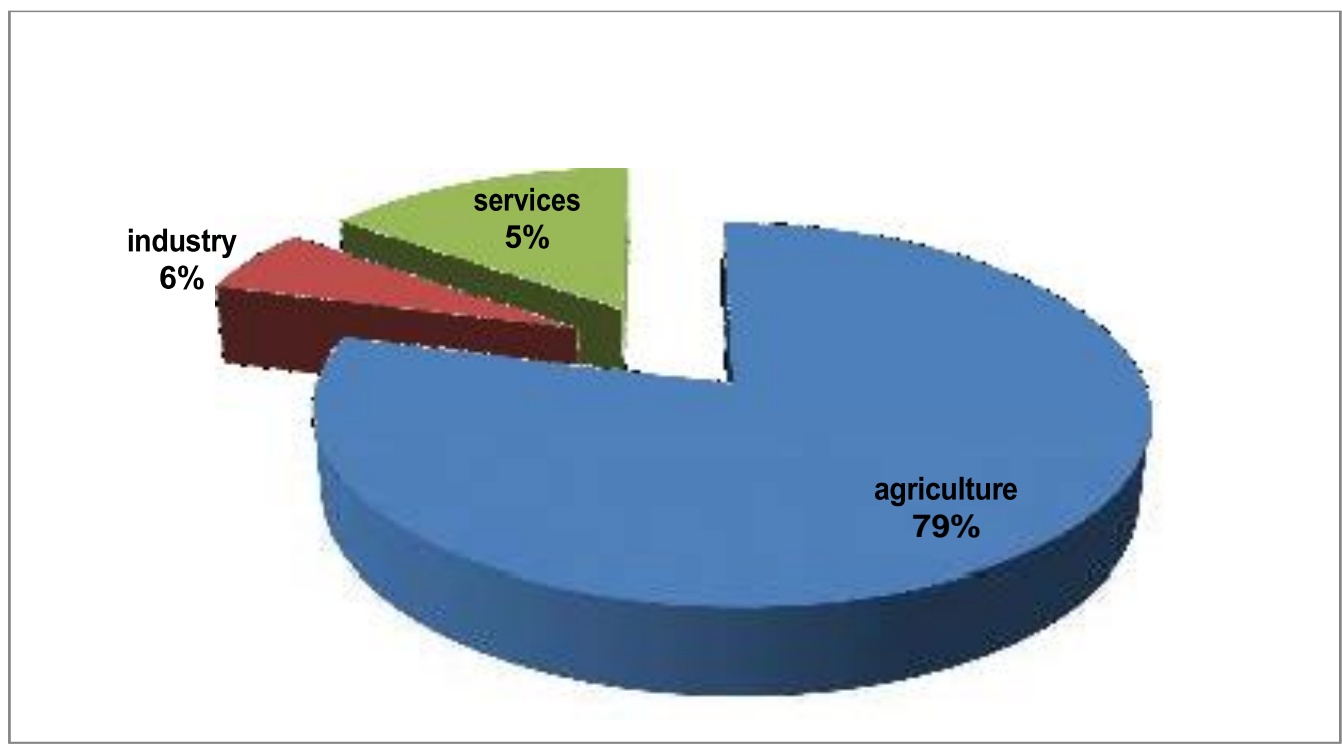

Source: Author' elaboration. 


\subsection{Agricultural Systems}

Agriculture is constituted as the main activity in Gadarif state. Hence, about $70 \%$ of the populations are working in the agricultural sector. The cultivable area is about 11.3 million feddans of improved and fertile lands. The rate of rain falling is about 100-500 millimeter in the year in the northern and western areas of the state and of about 500-900 in the east and south areas, which lay in the rich Savanna region.

There are two major types of agricultural systems in the state: the Rain fed and irrigated agriculture. Irrigated agriculture exists in the Rahad Scheme. The other type of agriculture is the Rain fed. It is divided into two types, traditional and mechanized farming. The former type is covering the most rain fed areas. Thus, the state is considered as the pioneer for this type of agriculture in Sudan. It started in the area of Gadambelya - $45 \mathrm{Km}$ west Gadarif city in the 1940s and then expanded to the most rain fed areas and became the main producer of Sorghum and Sesame in the country. Nevertheless, this type of agriculture is commercially oriented and most farmers depend on bank credits to finance their activities.

The traditional rain-fed agriculture, on the other hand, is existed around the villages in small farms known as (Bildat). The main crops cultivated here are Sorghum, Millet, and Sesame for subsistence purposes. Farmers in this type of agriculture use traditional forms of finance to run their activities. These forms are Sheil, Katafally, and Kasir). But these types of finance are highly cost and do force farmers to be in perpetual indebtedness.

The total agricultural land (11.3 million feddan) is distributed among the different types of farming and forestry as follows:
- Total arable land
8.602.600 feddans
- Forestry
2.732.700 feddans
- Grazing
4.200.000 feddans

\section{Analysis of Fiscal Decentralization in Gadarif State}

In this section, the implementation of fiscal decentralization in Gadarif state will be outlined and evaluated on the ground of revenues assignment, expenditure assignment and intergovernmental transfers to the state during the period (1998-2012).

\subsection{Assignment of Expenditure Responsibilities in Gadarif State}

Table (6) below explains the trends of total expenditure in Gadarif state during the period (1998-2012). 
Bongo, S. I. M. (2019). "Impact of Fiscal Decentralization on Local Autonomy in Sudan:

Experience of Gadarif State", International Journal of Public Finance, 4(1), 99-126.

Table 6: Budgeted and Total Expenditure of Gadarif State in the period (1997-2012) in Millions SDGs

\begin{tabular}{|c|c|c|c|}
\hline Year & $\begin{array}{c}\text { Budgeted Total } \\
\text { Expenditure }\end{array}$ & $\begin{array}{l}\text { Actual Total } \\
\text { Expenditure }\end{array}$ & $\begin{array}{c}\% \text { of } \\
\text { Actual/budgeted }\end{array}$ \\
\hline 1998 & 44.1 & 28.8 & $65 \%$ \\
\hline 1999 & 44.9 & 45.4 & $101 \%$ \\
\hline 2000 & 59.3 & 41 & $70 \%$ \\
\hline 2001 & 71.7 & 48.4 & $67 \%$ \\
\hline 2002 & 70.9 & 56.4 & $79 \%$ \\
\hline 2003 & 70.2 & 73.7 & $82 \%$ \\
\hline 2004 & 118.1 & 102 & $90 \%$ \\
\hline 2005 & 158.1 & 138 & $87 \%$ \\
\hline 2006 & 216.4 & 192 & $77 \%$ \\
\hline 2007 & 252.2 & 188 & $87 \%$ \\
\hline 2008 & 460.2 & 200 & $40 \%$ \\
\hline 2009 & 520.2 & 296 & $52.3 \%$ \\
\hline 2010 & 566.7 & 354.9 & $42.7 \%$ \\
\hline 2011 & 265.2 & 237.7 & $90 \%$ \\
\hline 2012 & 321.8 & 297.7 & $93 \%$ \\
\hline Average & & & $75 \%$ \\
\hline
\end{tabular}

Source: Ministry of Finance \& Labor Forces - various Economic Reviews.

Table 6 above and Figure 3 below show the instable fluctuations of the percentage of actual to the budgeted expenditure of the state, i.e., in 1999 it reported $101 \%$, while in the years 2008, 2009 and 2010 reported 40\%, 52.3\% and $42.7 \%$ respectively suggesting the weaker capability in preparing the budget in the state.

Figure 3: Budgeted and Actual Expenditure in Gadarif State (1998-2012) in Millions SDG

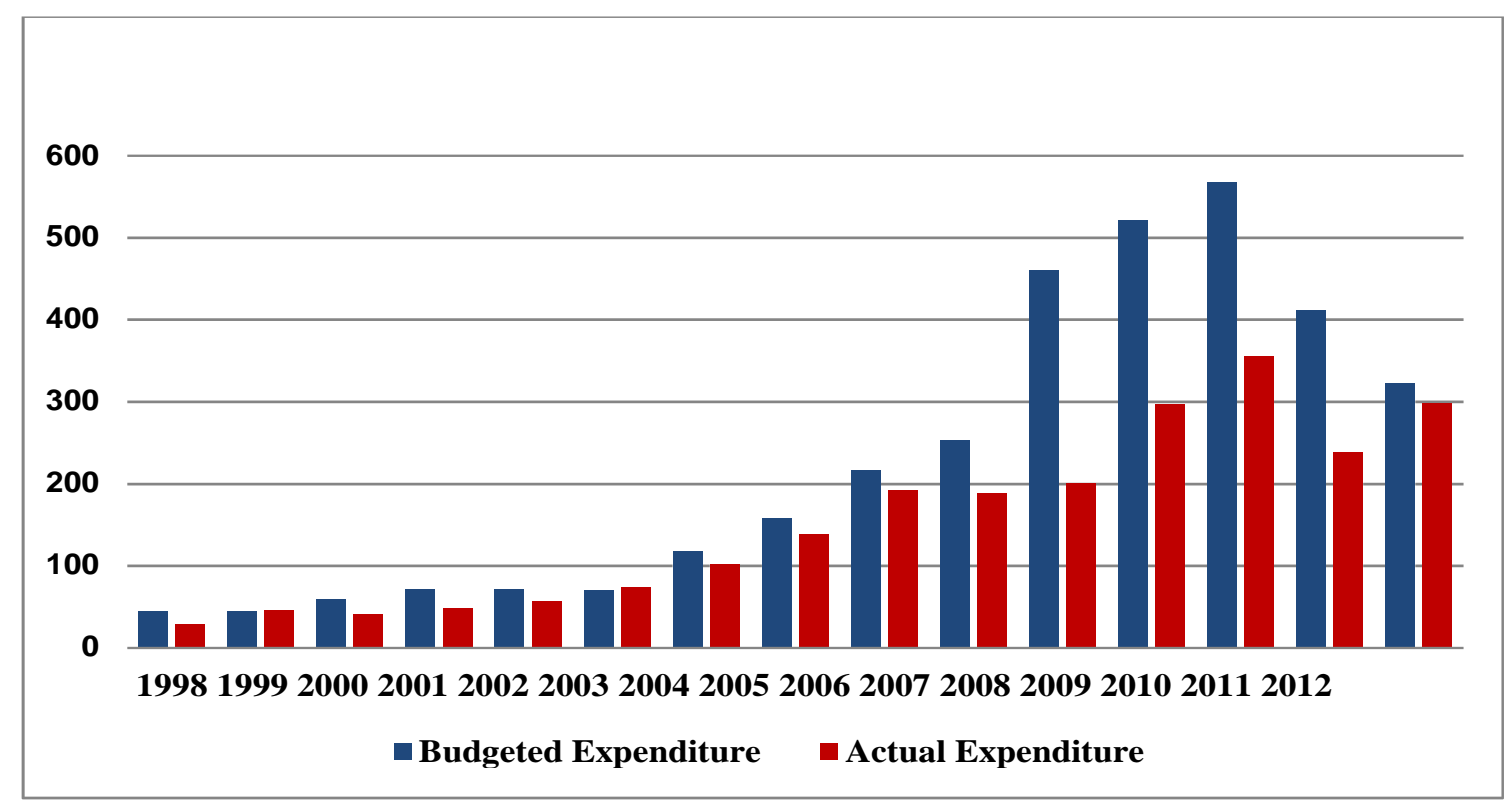

Source: Author' elaboration. 


\subsubsection{Expenditure Allocation in the state}

Figure 4 below shows the structure of the expenditure of the state in terms of its different chapters during the period (1998-2012). Chapter One indicates the salaries and wages; Chapter Two is of government expenditure on goods and services, chapter three exhibits capital goods and chapter four is of the development.

Figure 4: The Percentage Share of Different Chapters of the Budget in the Total Expenditure of the State in the period

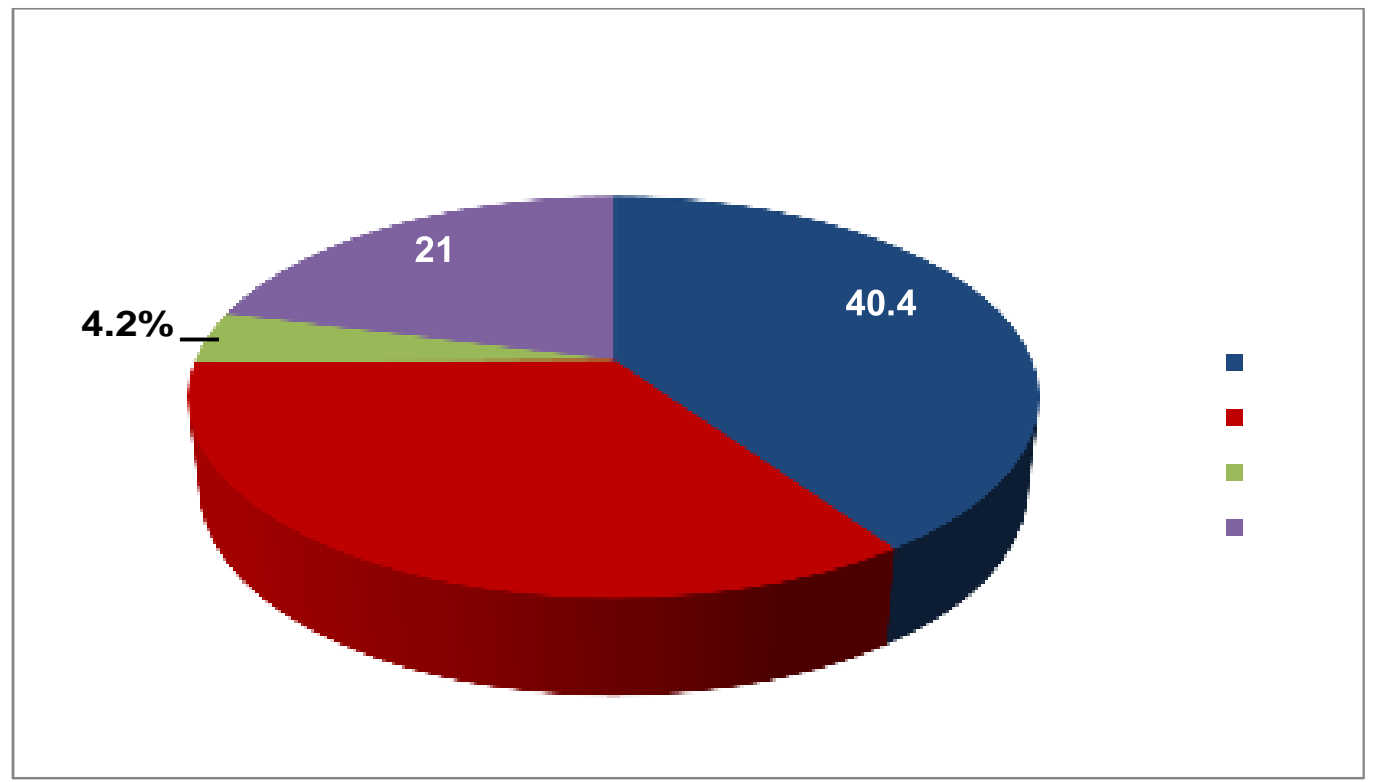

Source: Author' elaboration.

The table and the figure above indicate that only $21 \%$ of the budget devoted to the development in this period suggesting the poor performance of the services in the state, namely water, health, and education - furthermore, chapter one of the wages and salaries averages of the $40.4 \%$ of the budget.

\subsubsection{Regression Analysis}

In this context, two simultaneous equations will be attempted to investigate the expenditure and the revenue response to federal transfers and GDP of the state during the period (1998-2012). The importance of fiscal responsibility of the sub-national government analysis stems from that it is forecasting the impact of different transfer's designs on local fiscal behavior, which estimates both the level of transfers required and the impact of the transfers on their objectives. The similar analysis found in Bahl and Lin (1992), Gramlich (1977) and Mushkin \& Cotton (1968). 


\subsubsection{State Expenditure Response}

In this context, the total expenditure of the state is regressed to GDP and federal transfers of the period (1998-2012) to investigate the impact of federal transfers on expenditure by estimating the grant elasticity which indicates whether the transfers have stimulation or substitution impact on the state expenditure. To accomplish this objective, the following equation will be estimated:

$$
T E=\alpha_{0}+\alpha_{1} \text { Trans }+\alpha_{2} G D P+\mu_{t}
$$

Where

TE: is the Total Expenditure of the state

Trans: is the Federal Transfers to the state GDP: is the GDP of the state; and

$\mu \mathrm{t}$ : is the random variable

Time series data of the above variables of the period (1998-2012) have been used to investigate the factors affecting the total expenditure of the state. Results of the estimates of the equation are shown in Table 7 below:

Table 7: Results of Total Expenditure Equation Estimation of the period (1998-2010)

\begin{tabular}{|c|l|l|l|l|l|l|}
\hline $\begin{array}{c}\text { Dependent } \\
\text { Variable }\end{array}$ & \multicolumn{1}{|c|}{$\begin{array}{c}\text { Independent } \\
\text { Variable }\end{array}$} & \multicolumn{1}{|c|}{ Coefficient } & \multicolumn{1}{|c|}{ T-Value } & \multicolumn{1}{|c|}{ Sig. } & $\mathbf{R}^{\mathbf{2}}$ & F Change \\
\hline \multirow{2}{*}{ Log TE } & (Constant) & -9.6 & -3.4 & 00 & \multirow{2}{*}{0.89} & \multirow{2}{*}{$37.4^{*}$} \\
\cline { 2 - 5 } & Log GDP & 1 & 3.9 & 00 & & \\
\cline { 2 - 5 } & Log Trans & -0.06 & -0.3 & 0.8 & & \\
\hline
\end{tabular}

Source: Author' elaboration.

* Significant at $1 \%$

Results of Table 7 above show that an increase in one SDG in GDP associates with an increase in the total expenditure by the same value. About the transfers, it is found insignificant to total expenditure indicating that the increase in transfers has no substitution impact on the expenditure of the state. This result can be interpreted as that the central government deeply intervene in control and directing the federal transfer, affecting the fiscal autonomy of the state.

\subsection{Decentralization of Revenue Sources of the State}

In this part, the analysis will be emphasized on the performance of different revenues sources of the state, revenue effort, fiscal imbalance and the impact of federal 
transfers in the period (1997-2012). Figure 5 below shows the budgeted and the actual total revenues of the state during the period (1997-2012).

Figure 5: Budgeted and Total Actual Revenues in Gadarif State in the period (1999-2012) in Millions SDG

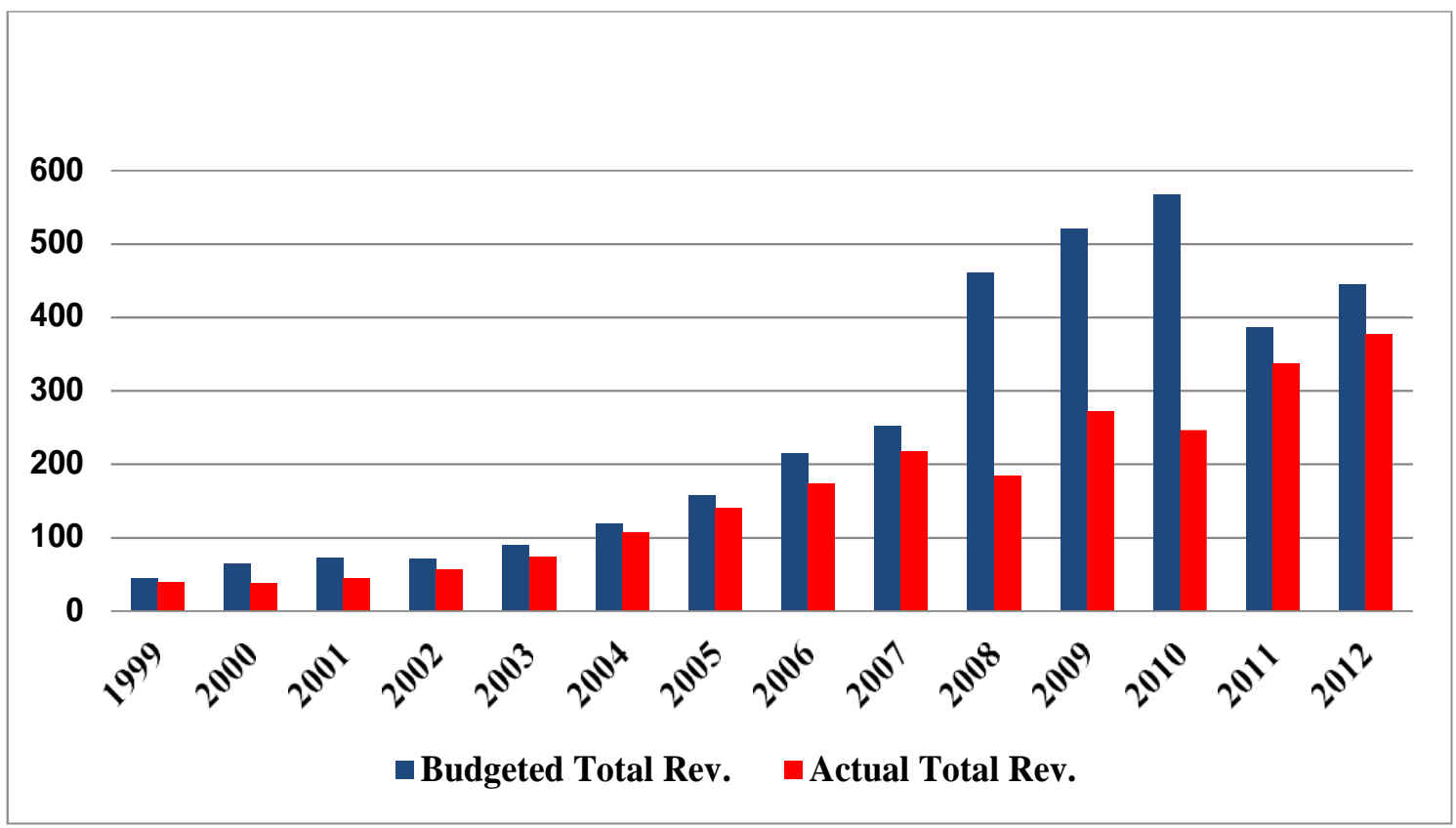

Source: Author' elaboration.

Figure 5 above shows that the actual total revenues of the state reported a weak performance in this period. For example, it accounted $71 \%$ of the budgeted total revenue and then witnessed a rapid deterioration in the next three years $(2008,2009$ and 2010 ) constituting of only $47 \%, 52 \%$, and $44 \%$ respectively. To promote the revenue performance of the state, detailed data of all revenue bases should be provided to set realistic and achievable revenues in the budget.

\subsubsection{Share of Different Sources in Total Revenues of the State}

Figure 6 below shows the share of different sources of revenues of the state during the period of the study.

Figure 6 explains that the gap between the own revenues of the state and the federal transfers is rapidly expanding by the time. Thus, in 1997 and 1998 the state is self-dependent. However, this situation is rapidly gone worst when the federal transfers reached $73 \%$ of the total state revenues in 2012 . This deterioration in the total revenue of the state is attributed mainly to the republican decree of 2001, which removed the tax on agriculture. As the state's economy is agricultural (about $89 \%$ of GDP of the state), 
the own revenue declined while the compensation made by the federal government failed to recover the fiscal imbalance made.

\section{Figure 6: Contribution of Different Sources in Total Revenues of the State in the} period (1997-2012)

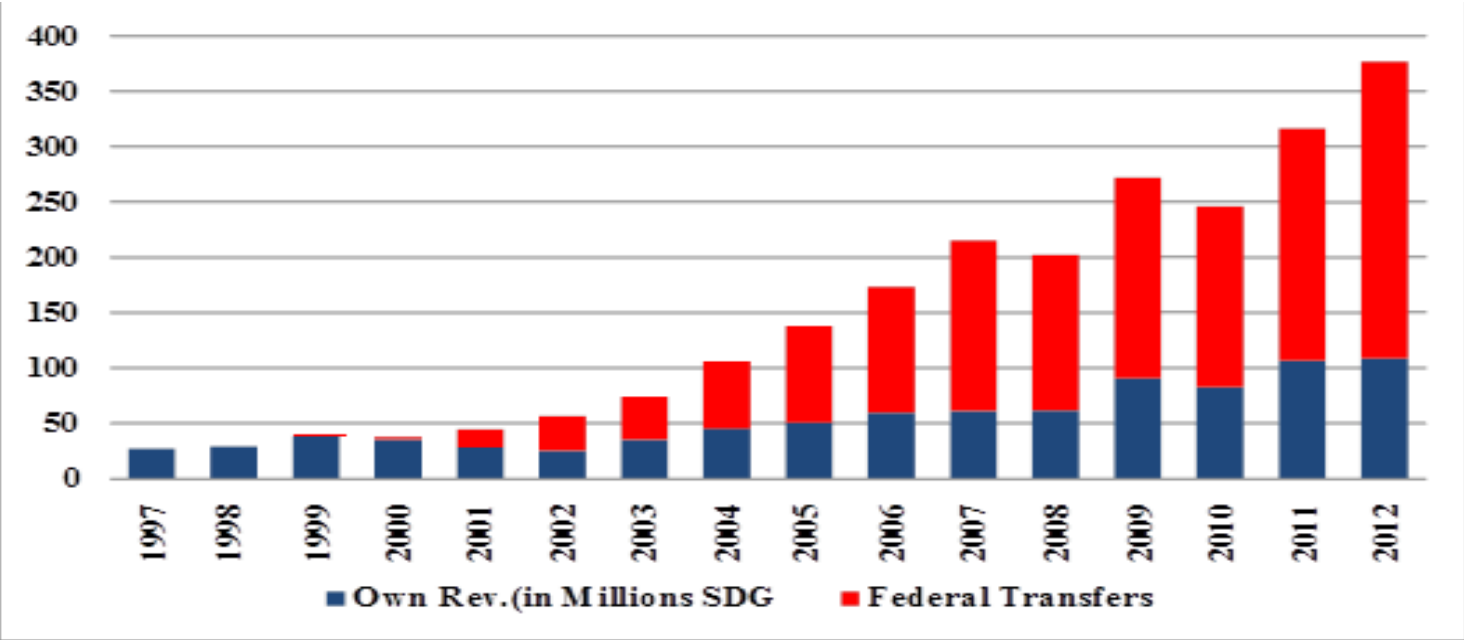

Source: Author' elaboration.

The figure below shows the percentage average shares of the own revenues of the state and the federal transfers in the period (1997-2012). It averages $56 \%$ and $44 \%$ respectively.

Figure 7: Percentage Average Share of Different Revenue Sources of the State (19972012)

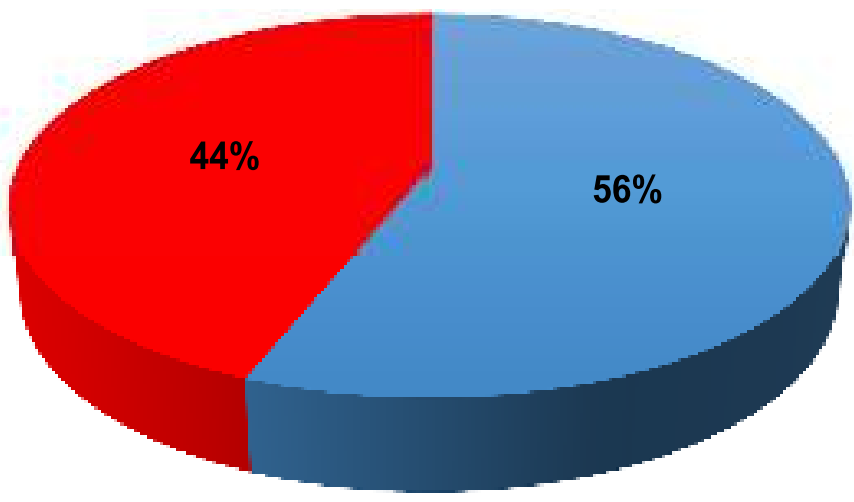

nown revenue $\quad$ transfers

Source: Author' elaboration. 
Bongo, S. I. M. (2019). "Impact of Fiscal Decentralization on Local Autonomy in Sudan:

Experience of Gadarif State", International Journal of Public Finance, 4(1), 99-126.

\subsubsection{Fiscal Imbalance in Gadarif State}

Table 8 below shows the vertical imbalance (VI) of the state during the period of the study. It is calculated as follows:

$$
V I=1-\frac{\text { Own Revenue }}{\text { Total Expenditure }}
$$

Table 8: Vertical Imbalance of Gadarif State during the period (1998-2012)

\begin{tabular}{|l|c|c|c|c|}
\hline Year & $\begin{array}{c}\text { (1) Own Rev.(in } \\
\text { Millions SDGs) }\end{array}$ & $\begin{array}{c}\text { (2) Total } \\
\text { Expenditure (in } \\
\text { Millions SDGs) }\end{array}$ & $\begin{array}{c}\text { (3)Imbalance } \\
\mathbf{( 1 / 2 )}\end{array}$ & $\begin{array}{c}\text { (4)Vertical } \\
\text { Imbalance 1- } \\
\text { (3) }\end{array}$ \\
\hline 1998 & 28.8 & 28.8 & 1.00 & 0 \\
\hline 1999 & 38.3 & 45.4 & 0.84 & 0.16 \\
\hline 2000 & 34.9 & 41 & 0.85 & 0.15 \\
\hline 2001 & 27.9 & 48.4 & 0.58 & 0.42 \\
\hline 2002 & 25.1 & 56.4 & 0.45 & 0.55 \\
\hline 2003 & 34.8 & 73.7 & 0.47 & 0.53 \\
\hline 2004 & 45.0 & 102 & 0.44 & 0.56 \\
\hline 2005 & 50.3 & 138 & 0.36 & 0.64 \\
\hline 2006 & 59.3 & 192 & 0.31 & 0.69 \\
\hline 2007 & 60.8 & 188 & 0.32 & 0.68 \\
\hline 2008 & 61.3 & 200 & 0.31 & 0.69 \\
\hline 2009 & 90.4 & 296 & 0.31 & 0.69 \\
\hline 2010 & 75.3 & 354.9 & 0.21 & 0.79 \\
\hline 2011 & 106.1 & 237.7 & 0.45 & 0.55 \\
\hline 2012 & 108.2 & 297.7 & 0.36 & 0.64 \\
\hline Average & & & & $\mathbf{0 . 5 2}$ \\
\hline
\end{tabular}

Source: Author' elaboration.

Figure 8: Own Revenues and Total Expenditure of the State in the period (1998-2012)

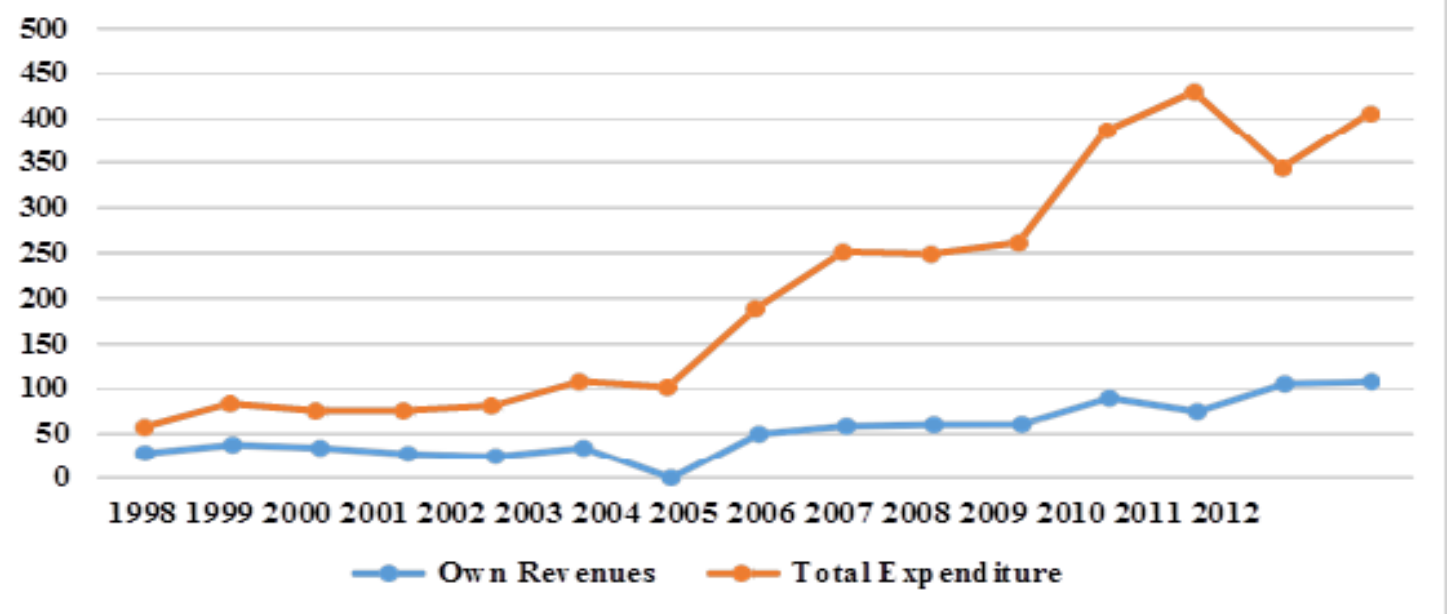

Source: Author' elaboration. 
Table 8 and Figure 8 above show that the vertical imbalance in the state is rapidly increasing, i.e., it growths from 16\% in 1999 to 79\% in 2010 indicating the higher deterioration of the fiscal performance of the state under fiscal decentralization. However, it averages of $52 \%$ in this period. This situation reflects the failure of the state to attain the fiscal autonomy and perform its responsibility of services provision to its constituents.

\subsubsection{Revenues Effort in Gadarif State}

Revenues effort is calculated as the ratio of total revenues of the state to GDP. It used to investigate whether the revenues collection reflects the economic activities in the state. Table 9 below presents the revenue effort of the state in the period (19982012).

Table 9: Revenue Effort in Gadarif State during the period (1998-2012)

\begin{tabular}{|l|c|c|c|}
\hline Year & $\begin{array}{c}\text { (1) GDP Millions } \\
\text { SDGs) }\end{array}$ & $\begin{array}{c}\text { (2)Total Revenue } \\
\text { (Millions SDGs) }\end{array}$ & (3) Revenue efforts (2)/(1) \\
\hline 1998 & 1022.5 & 27.1 & 0.03 \\
\hline 1999 & 1113.3 & 28.8 & 0.03 \\
\hline 2000 & 1314.5 & 38.9 & 0.03 \\
\hline 2001 & 1236.1 & 37.6 & 0.04 \\
\hline 2002 & 1542.9 & 44.6 & 0.04 \\
\hline 2003 & 1532.6 & 56.3 & 0.05 \\
\hline 2004 & 1597 & 73.8 & 0.07 \\
\hline 2005 & 1720 & 106.8 & 0.08 \\
\hline 2006 & 1752.8 & 140 & 0.10 \\
\hline 2007 & 1826 & 173 & 0.12 \\
\hline 2008 & 1980 & 216.4 & 0.09 \\
\hline 2009 & 2039.3 & 183.8 & 0.13 \\
\hline 2010 & 2230.9 & 271.9 & 0.11 \\
\hline 2011 & 2440.4 & 337.1 & 0.14 \\
\hline 2012 & 2667.4 & 376.8 & 0.14 \\
\hline Average & & & $\mathbf{0}$ \\
\hline
\end{tabular}

Source: Author' elaboration.

Table 9 above shows the poor performance of revenues effort of the state. Hence, it averages only $8 \%$ in the above period. This situation can be attributed to the inadequate assignment of revenues sources, i.e., most revenues sources assigned to the state level were inefficient and highly conflicting with the constituents. Moreover, the higher tax evasion, weak personnel, and wide exemptions were also responsible for the weak performance of the revenue effort of the state. 
Bongo, S. I. M. (2019). "Impact of Fiscal Decentralization on Local Autonomy in Sudan:

Experience of Gadarif State", International Journal of Public Finance, 4(1), 99-126.

\subsubsection{Share of Tax and Non-tax Revenues in total State Revenues}

Table 10 below shows the share of tax and non-tax revenues in total revenue of the state in the period (1997-2012).

Table 10: Tax and non-tax Revenues (in a million SDGs) in Gadarif State (1997-2012)

\begin{tabular}{|c|c|c|c|c|}
\hline Year & Tax Rev. & \%of State Rev. & Nontax & \% of State Rev. \\
\hline 1997 & 6.4 & 23.5 & 20.7 & 76.5 \\
\hline 1998 & 5.8 & 20.1 & 23 & 79.1 \\
\hline 1999 & 8.7 & 22.7 & 30.2 & 77.3 \\
\hline 2000 & 5.1 & 13.7 & 23.9 & 86.3 \\
\hline 2001 & 4.7 & 16.8 & 39.9 & 83.2 \\
\hline 2002 & 4.9 & 19.5 & 51.4 & 80.5 \\
\hline 2003 & 5.9 & 17 & 67.9 & 83 \\
\hline 2004 & 7.2 & 16 & 99.6 & 84 \\
\hline 2005 & 9.1 & 18 & 130.9 & 82 \\
\hline 2006 & 13.6 & 23 & 159.4 & 77 \\
\hline 2007 & 15.8 & 26 & 200.6 & 74 \\
\hline 2008 & 17.2 & 29 & 166.6 & 71 \\
\hline 2009 & 27 & 29.9 & 244.9 & 64.5 \\
\hline 2010 & 29.2 & 35.5 & 216.7 & 89.3 \\
\hline 2011 & 36.2 & 10.7 & 301 & 86.7 \\
\hline 2012 & 50.1 & 13.3 & 326.7 & 79.1 \\
\hline Average & & 20.9 & & \\
\hline
\end{tabular}

Source: Author' elaboration.

\subsubsection{Calculation Using Data of the Ministry of Finance \& Labor Forces-Gadarif State.}

Table 10 and Figure 9 explains the higher distortion of the revenue structure of the state reflected by the rapid deterioration of the tax revenues compared to the nontax revenues, which averages of $79.1 \%$ of the total revenue of the state in the above period. This situation is mostly due to the removing of the agricultural tax in 2001. However, the failure of revenue assignment is also responsible for this situation.

Figure 9: Percentage Share of Tax and Non-tax Revenue in Own revenues of the State (1997-2012)

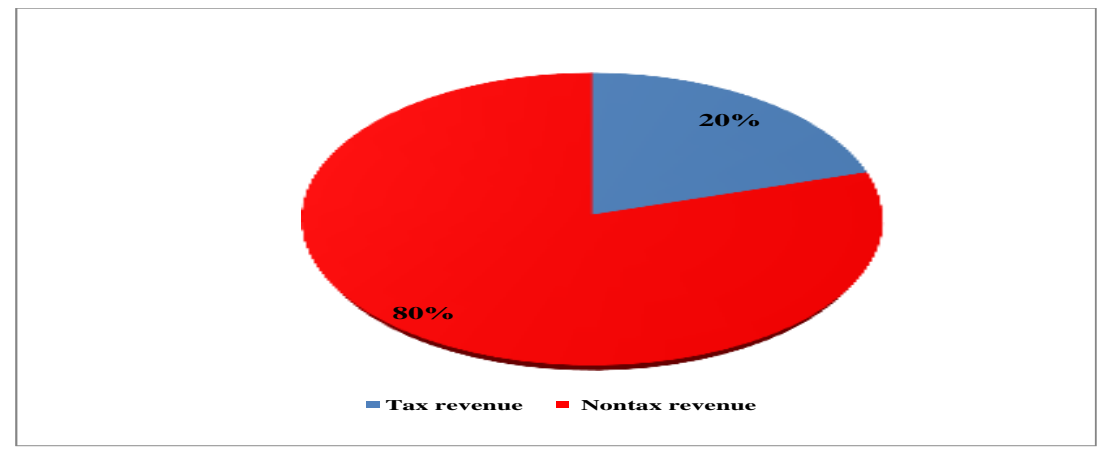

Source: Author' elaboration. 


\subsubsection{Impact of transfers on the state revenues (regression analysis)}

In this consider, data of state revenues (Strev), transfers from the federal government (Trans) and the GDP of the state of the period (1998-2012) will be used to examine the response of state revenues to federal transfers. Thus, the parameters of the following equation will be estimated:

$$
\text { Strev }=\alpha_{0}+\alpha_{1} \text { Trans }+\alpha_{2} G D P+\mu_{t}
$$

Using OLS technique for data of the above variables in logarithmic form, table (11) presents estimates of the above equation.

Table 11: Estimates of state revenues equation of the period (1998-2012)

\begin{tabular}{|l|l|l|l|l|l|l|}
\hline $\begin{array}{c}\text { Dependent } \\
\text { Variable }\end{array}$ & \multicolumn{1}{|c|}{$\begin{array}{c}\text { Independent } \\
\text { Variable }\end{array}$} & Coefficient & T-Value & Sig. & $\mathbf{R}^{\mathbf{2}}$ & F Change \\
\hline \multirow{2}{*}{ logStrev } & (Constant) & $-6.511-$ & -2.719 & .024 & $73 \%$ & $12^{*}$ \\
\cline { 2 - 6 } & LogTrans & -.134 & -1.455 & .18 & & \\
\cline { 2 - 6 } & LogGDP & 2.616 & 3.325 & .01 & & \\
\hline
\end{tabular}

Source: Author' elaboration.

* Significant at $5 \%$

Results shown in Table 11 reveal that variations in state revenues are not responding to the federal transfer's variations (it found insignificant), indicating the failure of one of the basic objectives of the federal transfers of inducing the local revenues - by directing the transfers to productive channels. However, the GDP is found significant at $1 \%$ with higher elasticity (2.6)

\section{Concluding Remarks}

This study aimed at evaluating the experience of fiscal decentralization of Gadarif state in the period (1997-2012). Therefore, expenditure decentralization, revenue decentralization, and fiscal imbalance were analyzed in the context of the fiscal decentralization objectives. To accomplish these objectives, different methods have been utilized. Indicators of revenue effort and fiscal imbalance were calculated to evaluate the performance of revenue and expenditure assignment in terms of fiscal autonomy and fiscal imbalance. Time series regressions of data for the period (19982012) were attempted to investigate the response of revenue, expenditure, and transfers to their different arguments. 
Results of the study revealed that the fiscal situation of the state had rapidly deteriorated since the implementation of the fiscal decentralization system in 1995. Thus, no fiscal autonomy has been realized as the federal transfers constituted of about $73 \%$ of the total state revenues in 2012 and the revenue effort is reported only to $8 \%$ of GDP as the average of the period (1998-2012). The vertical imbalance averaged $52 \%$ in the same period. The regression results also indicated that the state revenues were not responding to federal transfers.

To promote the fiscal decentralization system and to overcome the poor situation concerning revenue and expenditure of Gadarif state, emphasis should be directed to different aspects. These policy measures recommended are:

- Revenue administrators should be empowered to increase their revenue to acquire fiscal autonomy.

- Provision of detailed information about the different revenue source bases to help to set achievable targets for revenues in the budget.

- Local administrations should be given clear assignments about their revenue and expenditure responsibilities.

- Directing the transfers to productive channels.

\section{References}

Ali, A.A. (2007). Intergovernmental Transfers in Sudan: A proposed approach for Horizontal Distribution, UNICONS, Khartoum Sudan.

Bell, M.E \& Ahmed, M.M. (2005). Fiscal Decentralization in the Sudan: Concepts and Challenges, George Washington Institute of Public Policy, Working Paper No 10.

Bessie, M. (2004). "Fiscal Decentralization in Benishangul Gumoz Region: A review of Problems of Fiscal imbalance" in published MSc. thesis at the University of Addis Ababa.

Comprehensive Peace Agreement (2005).

De M. \& Luiz R. (2000). “Fiscal Decentralization and Intergovernmental Fiscal Relations: A Cross-Country Analysis", World Development, 28(2), 365-380.

Elbadawi, I. \& Kabbashi S. (2008). "Toward an Equitable Intergovernmental Transfer System for the Sudan", Generating Growth and Making Fiscal Decentralization Works in Post-Conflict Sudan, (Eds.) Abdelrahman, Saifeldin D, Ministry of Finance and National Economy, Sudan, 97-115. 
Elbattahani, A. (2008). "Fiscal Federalism and Institutional Development: Analyzing the Conundrum of De-centering the Centre in Post Conflict Sudan", Generating Growth and Making Fiscal Decentralization Works in Post-Conflict Sudan, (Ed.) Abdelrahman, S.D., Ministry of Finance and National Economy, Sudan, 79-97.

Elbattahani, A. \& Gadkarim (2017). Governance and Fiscal Federalism in Sudan, 19892015: Exploring Political and Intergovernmental Fiscal Relations in a Stable Policy, University of Bergen, CMI.

Elshibly, M.M. (1990). Fiscal Federalism in Sudan, Khartoum University Press.

Elshibly, M.M. (2013). Fiscal Transfers: Towards a Pro-poor System, Assessment of the existing Inter-Governmental Fiscal Transfers System in Sudan, UN, Country Office Sudan.

Gangi, Y. \& Ibrahim, G. (2008). "Institutionalist Perspective on Decentralization in Sudan", Generating Growth and Making Fiscal Decentralization Works in PostConflict Sudan, (Eds.) Abdelrahman, Saifeldin D, Ministry of Finance and National Economy, Sudan, 116-126.

Joint Assessment Mission (JAM) (2005). Framework for Sustained Peace, Development and Poverty Eradication, https://postconflict.unep.chsudanreport/sudan_ website/doccatcher/data/documents/Joint20Assessment20Mission20(JAM)20V olume20l.pdf, (20.04.2019).

Mohamed, S.I. (2017). "Restructuring Intergovernmental Fiscal Relations to Enhance Growth and Development in Post-Secession Sudan", Journal of Public Economics and Finance, December, 4(1), 1-36.

Musgrave, R.A. \& Musgrave, P.B. (1984). Public Finance in Theory and Practice, 4. Ed., McGraw-Hill New York.

Oates, W. (1999). "An Essay on Fiscal Federalism". Journal of Economic Literature, 37, 1120-1149.

Oates, W. (1972). Fiscal Federalism. Harcourt, Jovanovich.

Sagbas, I. (2001). “An Econometric Analysis of Local Fiscal Response to Revenue Sharing in Turkey", Economic and Planning Council: Government and Policy, 19, 85-101.

Shah, A. (1991). Perspectives on the Design of Intergovernmental Fiscal Relations, The World Bank Working Papers.

Shah, A. (2004). "Fiscal Decentralization in Developing and Transition Economies: Progress, Problems, and the Promise". World Bank Policy Research Working Paper No.3282.

Shah, A. (1997). "Balance, Accountability, and Responsiveness: Lessons about Decentralization", World Bank Conference on Evaluation and Development, April 1-2. 
Bongo, S. I. M. (2019). “Impact of Fiscal Decentralization on Local Autonomy in Sudan:

Experience of Gadarif State", International Journal of Public Finance, 4(1), 99-126.

Tiebout, C.M. (1956). "A Pure Theory of Local Expenditure". Journal of Political Economics, No. 5, 416-424.

The Interim National Constitute of the Republic of the Sudan (2005). https://www.wipo.int/edocs/lexdocs/laws/en/sd/sd003en.pdf, (20.04.2019)

UNDP (2005). Fiscal Decentralisation and Poverty Reduction, http://unpan1.un.org/intradoc/groups/public/documents/un/unpan030970.pd f, (20.04.2019)

Vazquez, J.M. \& Robert M.M. (2002). "Fiscal Decentralization and Economic Growth", International Studies Program - Working Paper No. 01. 